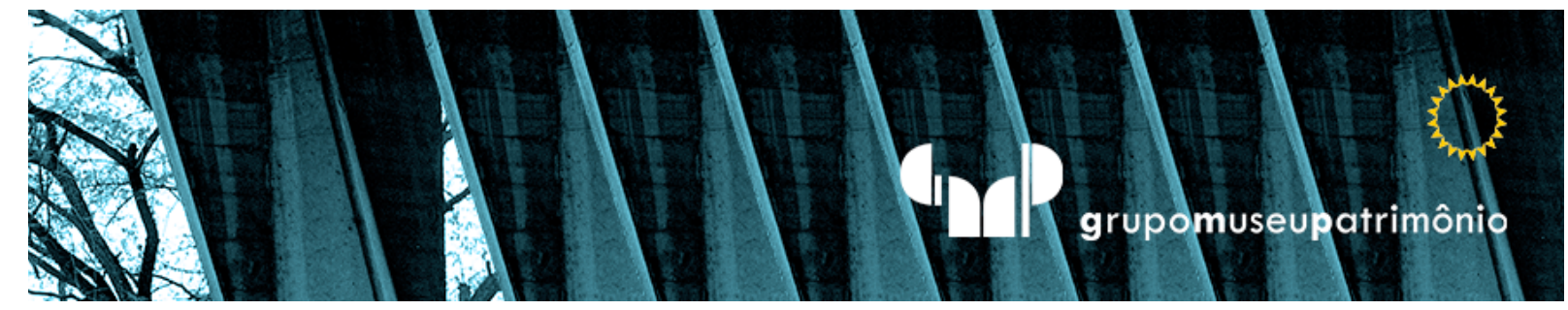

\title{
Na rede das apropriações: produção artística de resistência à iconomania
}

En la red de apropriaciones: producción artística de resistencia a la iconomanía

In the network of appropriations: artistic production of resistance to iconomania

José Bento Machado Ferreira

Pós-Graduação Interunidades em Estética e História da Arte da USP, São Paulo, Brasil.jbmferreira@usp.br 


\section{Resumo}

Obras de arte promovem anacronismos e produzem imagens críticas. Trabalhos criados pela dupla de artistas Basel Abbas e Ruanne Abou-Rahme podem ser pensados a partir das ideias de Marie-José Mondzain, Georges DidiHuberman e Hans Belting, que se ocupam das implicações antropológicas, políticas e estéticas da questão das imagens na cultura contemporânea.

Palavras-Chave: Iconomania. Iconotopia. Iconochoque. Heterotopia. Anacronismo.

\section{Resumen}

Las obras de arte promueven anacronismos y producen imágenes críticas. Las obras creadas por el dúo de artistas Basel Abbas y Ruanne Abou-Rahme pueden pensarse a partir de las ideas de Marie-José Mondzain, Georges DidiHuberman y Hans Belting, que abordan las implicaciones antropológicas, políticas y estéticas del tema de las imágenes en la cultura contemporánea.

Palavras-Clave: Iconomanía. Iconotopia. Iconoschock. Heterotopía. Anacronismo.

\section{Abstract}

Artworks promote anachronisms and produce critical images. Works created by artist duo Basel Abbas and Ruanne Abou-Rahme can be thought from the ideas of Marie-José Mondzain, Georges Didi-Huberman and Hans Belting, who deal with the anthropological, political and aesthetic implications of the issue of images in culture contemporary.

Keywords: Iconomania. Iconotopia. Iconoclash. Heterotopia. Anachronism. 
A nd yet my mask is powerful ${ }^{1}$, da dupla de artistas Ruanne Abou-Rahme e Basel Abbas, que vive em Ramallah, resulta de excursões para ruínas de cidades palestinas no Estado de Israel (fig. 1). Além da linguagem da deriva, outros procedimentos contribuem para o teor crítico das imagens que compõem o trabalho: a apropriação de trechos do poema Mergulhando no naufrágio (Adrienne Rich, 1973) e a reprodução de máscaras neolíticas. A coleta de objetos encontrados no meio e apresentados ao lado de impressões de tela de computador com registros de pesquisas na internet (fig. 2) integram-se ao conjunto dos procedimentos de deslocamento, apropriação ou desvio que Asger Jorn e Guy Debord chamaram de détournement e de que o crítico Nicolas Bourriaud se vale para propor a ideia de "pós-produção" (2009, p. 36).

\footnotetext{
1 "Ainda assim a minha máscara é poderosa", título extraído de verso do poema Diving into the wreck, "mergulhando no naufrágio", de Adrienne Rich (1929-2012), sendo a máscara em questão uma máscara de mergulho, que tem o poder de proporcionar oxigênio para o mergulhador.
} 


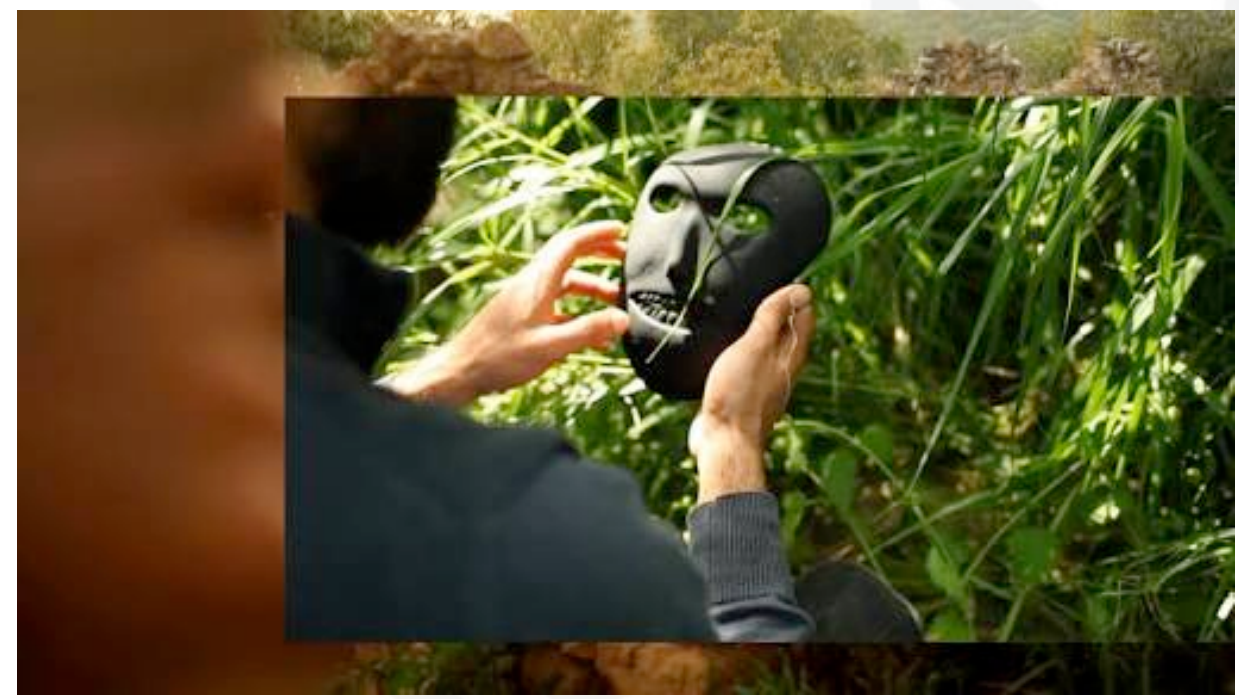

Figura 1: And yet my mask is powerful, still de vídeo. Fonte: Basel Abbas \& Ruanne Abou-Rahme (reproduzido sob permissão).

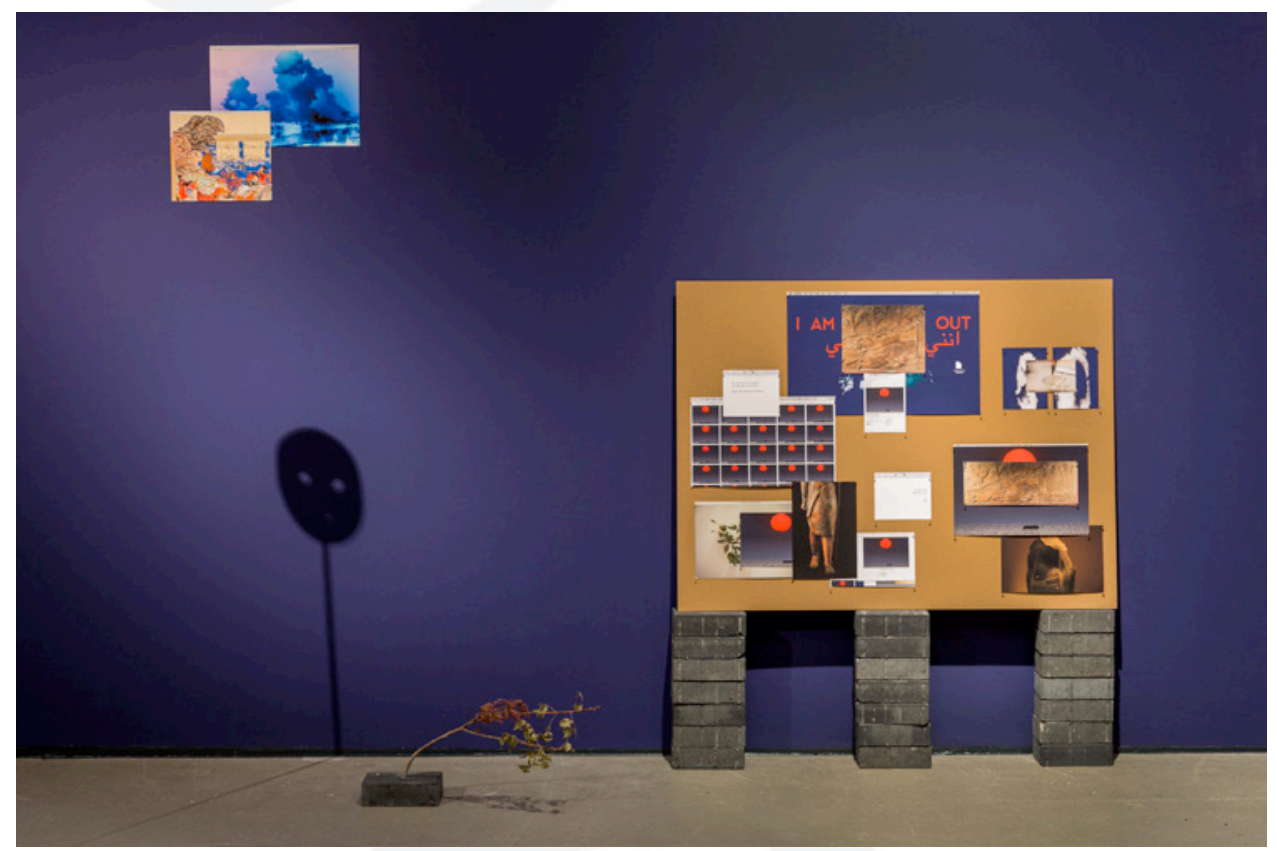

Figura 2: And yet my mask is powerful, vista da instalação. Fonte: Basel Abbas \& Ruanne Abou-Rahme (reproduzido sob permissão).

Os artistas produziram imagens das derivas em meio a lugares vazios nos quais revelam ruínas e coletam plantas típicas palestinas. Nas derivas, utilizam 
impressões tridimensionais de máscaras neolíticas possuídas por colecionadores e abrigadas no Museu de Israel em Jerusalém, o que motiva os artistas: “[...] nós nos interessamos pelo modo como essas máscaras foram basicamente saqueadas da Cisjordânia e em como são usadas pelo Estado de Israel para criar uma mitologia sobre o Estado". ${ }^{2}$ Esse conjunto de ações propõe considerações sobre o estatuto da imagem na contemporaneidade e sobre como as obras de arte podem produzir imagens críticas, que se contrapõem à hegemonia do olhar, ao olhar dominante. A contraposição entre imagens críticas e um olhar dominante foi caracterizada por Georges DidiHuberman pelo binômio "vaga-lumes" e "holofotes" a partir de relatos do cineasta e escritor Pier Paolo Pasolini (DIDI-UBERMAN, 2011, p. 25). O termo "imagens críticas" provém de Gilles Deleuze (2005, p. 32). A idéia de hegemonia do olhar refere-se ao conceito de "iconocracia", que Marie-José Mondzain define como "[...] organização do visível que provoca uma crença e que também pode ser chamada de submissão ao olhar", o que remontaria às "batalhas" bizantinas entre iconoclastas e iconófilos (MONDZAIN, 2000, p. 59).

As derivas transformam lugares vazios em lugares de memória. Segundo a terminologia de Pierre Nora, lugares da "memória verdadeira", que não passou para a história e refugia-se "[...] no gesto e no costume, nas atividades que transmitem os saberes do silêncio, nos saberes do corpo, as memórias de impregnação e os saberes reflexos" (NORA, 1992, p. xxv). O movimento dos corpos através da fronteira, desbravando o território tomado pela natureza, explorando ruínas, descobrindo túneis, coletando objetos, desperta uma memória que não é a "memória arquivo" conforme Nora, "uma memória secundária, memória-prótese", mas a própria "passagem da memória à história" (1992, p. xxvii), ainda que fadada a ser interrompida, uma vez que as cidades destruídas estão à beira do esquecimento e uma vez que essa prática artística não tem o poder de erigir monumentos, os marcos institucionais dos lugares de memória. Monumentos se erguem sem as marcas do tempo, como

\footnotetext{
${ }^{2}$ Declaração de Basel Abbas em material de divulgação da galeria Carroll/Fletcher.
} 
antíteses do esquecimento. As obras de arte expõem o esquecimento tanto quanto a memória, ou a experiência do esquecimento que necessariamente antecede, pressupõe e tende a ser negada pela experiência da memória, conforme o raciocínio de Andreas Huyssen: “[...] a política de memória não pode prescindir do esquecimento" (HUYSSEN, 2014, p. 160). Assim, a condição de ruína encoberta pelo mato e marcada pela intempérie, não a ruína monumental, mas uma ruína recente, invisível e esquecida, não assoma senão por meio dos procedimentos que tornam visível o esquecimento a que foi submetida, trazendo à tona "o estrago que foi feito e os tesouros que restaram" segundo o poema de Adrienne Rich, "a prova do dano".

É da própria natureza das obras de arte uma condição "híbrida" conforme afirma Nora acerca dos lugares de memória. Elas não são meras coisas, enquanto gestos e ações, mas também são coisas, enquanto vestígios e imagens, possuem uma "contraparte material" (DANTO, 2005, p. 163); portanto, estão sujeitas aos sistemas de circulação, à especulação sobre o valor, à assimilação por parte das próprias estruturas que denunciam. Porém a utilização de determinados recursos, como apropriação, deslocamento e deriva, aos quais poderíamos acrescentar o novo, o acaso, a alegoria e a montagem, perfazendo assim todos os aspectos do "outro conceito de obra de arte" enumerados por Peter Bürger (p. 124), asseguram o "potencial de resistência" da obra de arte, conforme formulação de Adorno. Não sendo monumentos, trata-se de imagens-testemunhos, modos de "escrever a história a contrapelo" segundo Benjamin (LÖWY, 2014, p. 70). Lembram o que foi esquecido e liberam a força e a ferocidade do "passado indomado" (ARENDT, 2017, p. 306), expõem tensões não resolvidas e feridas abertas.

O "lugar vazio" explorado pelos artistas forma-se no rastro dos "não-lugares", conforme o processo descrito por Marc Augé: “[...] espaços onde não se pode vislumbrar nenhuma relação social, onde nenhum passado partilhado se inscreve" (2010, p. 36). Desde os situacionistas, formuladores da "deriva", ou dos surrealistas, seus precursores ao descobrir "lugares sagrados" em "encontros fortuitos" (BÜRGER, 2008, p. 135), essa prática artística, ou 
procedimento, traz à tona o significado coletivo que havia sido depositado no lugar vazio e que foi esquecido. Todo espaço tem significado coletivo, um "passado partilhado", ainda que imaginário. Até mesmo espaços naturais como o oceano, a caverna, a floresta, o espaço sideral e o deserto; lugares ermos, vazios, compõem o imaginário, são "lugares simbólicos" (DUBY, 2009, p. 323) e, portanto, existem cultural e socialmente. Eremitas foram movidos pelo "desejo de atingir mais perfeição no deserto" (DUBY, 2009, p. 535), em grego éremos (ermo), por exemplo. Porém o significado coletivo do espaço, que the confere o estatuto de "lugar antropológico" (AUGÉ, 2003, p. 19) por oposição a um não-lugar, tende a ser apagado pelos processos de urbanização, modernização, colonização, ou ocupação. Fazer ressurgir o "passado partilhado" nos lugares vazios à margem dos não-lugares seria então uma forma de descolonizar o espaço por meio da produção de imagens críticas.

Uma das cenas de And yet my mask is powerful mostra os participantes de costas, observando uma ruína tomada pelo mato, com uma estrada movimentada ao fundo. A posição dos participantes retoma um recurso utilizado na pintura por Caspar David Friedrich (1774-1840) para ressaltar a presença de um espectador interno, alguém que não aparece, mas que é o sujeito do olhar representado na imagem, que equivale ao olhar do espectador externo, o "nosso" olhar:

\footnotetext{
Esta figura ou estas figuras - pois quase sempre estão aos pares ou em grupos de três - têm estreita relação com o espectador no quadro. Não são esse espectador, mas seus clones, de modo que se pode imaginar que ele se sente arrastado - arrastado diante de si mesmo, por assim dizer - mais profundamente no espaço ao qual pertence: empurrado da parte não representada para dentro da parte representada. (WOLLHEIM, 2002, p. 168)
}

Assim, tanto no poema, em que a figura do mergulhador que visita o naufrágio atua como essas "figuras de costas" que Wollheim vê na pintura de Friedrich, quanto nos registros das derivas, o olhar pressupõe um espectador interno, por sua vez sujeito a um "choque". A ruína é o vestígio de uma cidade palestina, a estrada é israelense e as "figuras de costas" são moradores da Cisjordânia que atravessaram a fronteira para caminhar, observar e registrar 
seu testemunho em forma de imagens. Somos empurrados e recuamos dos abismos e horizontes de Caspar David Friedrich por causa da presença dessas figuras. Também a imagem da dupla palestina "arrasta mais profundamente no espaço" o olhar desse terceiro participante cujo olhar, no caso a câmera, equivale ao "nosso", os espectadores externos. Analogamente à pintura de Friedrich, nosso olhar também recua, não mais diante da paisagem, mas, como diria Didi-Huberman, diante do tempo, ou seja, do passado que "retorna como anacronismo" (2015, p. 174), experiência que a imagem proporciona ao fazer ressurgir o significado coletivo da memória em meio aos não-lugares. Ao mesmo tempo fronteira e não-lugar, o túnel sob o Canal da Mancha não aparece em Border (Laura Waddington, 2004), mas é para ele que rumam os refugiados acampados em Sangatte no vídeo que o filósofo caracterizou como “imagens-vaga-lumes" (2011, p. 156). O olhar da câmera de Border esgueira-se furtivamente pelo matagal com os vultos dos refugiados, sob um céu noturno tingido de roxo e contra os holofotes de vigilância. Assim como a memória de juventude de Pasolini que inspira a metáfora dos vaga-lumes como imagens de resistência aos holofotes, figura da iconocracia, trata-se da caminhada por um lugar vazio que traça uma "linha de fuga" e ao atravessar o não-lugar das fronteiras promove "desterritorialização" (DELEUZE, 1998, p. 49).

As imagens críticas acontecem no contexto dos espaços de "contraposicionamento" (FOUCAULT, 2009, p. 415), ou "contraespaços" (Foucault, 2013, p. 20), em que o passado partilhado surge como anacronismo. Imagens aglutinam laços comunitários e sua contraparte material explica por que elas tradicionalmente se associam a lugares, o que Gruzinski (2006) e Belting (1994) demonstram nos estudos sobre o culto às imagens. A relação entre a obra de arte e o espaço ao redor caracteriza os desdobramentos do modernismo no século vinte, seja como "espaço em obras" ou "campo expandido" conforme os críticos Alberto Tassinari e Rosalind Krauss. A palavra "aura" é usada por Belting (1994, p. 48) para designar o que os antropólogos como Gell chamam de "agência" da imagem sobre as pessoas, o poder das 
imagens. Uma releitura do conceito benjaminiano de aura promovida por DidiHuberman ressalta a conexão entre imagens e o lugares:

O enunciado benjaminiano da aura mostra-se particularmente válido nesse contexto das "Santas Faces", porque o valor de culto dos objetos - a sua eficácia antropológica, a sua legitimidade teológica, a sua coerência litúrgica - aí se exprime através de uma certa intermediação do lugar, uma certa configuração dada à relação entre o próximo e o distante. (DIDI-HUBERMAN, 2015b, p. 178)

A "aparição única de algo distante por mais próximo que esteja" (BENJAMIN, 2012, p. 16) está ligada ao lugar da imagem por oposição à reprodutibilidade técnica, que inaugura o reino das imagens sem lugar, que abolem a distância inerente à unicidade, que permitem aproximações "cirúrgicas" ${ }^{3}$ e que proporcionariam os novos meios para uma arte revolucionária, a "politização da arte" (2012, p. 36), embora o autor já alertasse para os perigos da apropriação fascista desses meios, a "estetização da política".

\section{A VIDA NUA DAS IMAGENS}

Um dos desdobramentos da perda da aura é, com a "morte do referencial divino" (BAUDRILLARD, 1991, p. 16), uma infestação de imagens sem significado, ou cujo significante está "pairando livremente", uma vez que "perdeu seu significado", ou "cujos significados tenham evaporado", de acordo com a descrição de Jameson da relação esquizofrênica com as imagens na pósmodernidade (1985, p. 23-24). Propomos utilizar a expressão "vida nua" para caracterizar a condição dessas imagens sem significado, em parte por analogia à recorrência da figura retórica da vivacidade das imagens, mas principalmente com referência à ideia de "sobrevivência", que remonta a Warburg (DIDIHUBERMAN, 2013) e que Didi-Huberman situa no centro de uma "história da arte aberta a problemas antropológicos" (2013, p. 69). A ideia de vida nua perpassa a obra de Giorgio Agamben, que a apresenta como "protagonista" na

\footnotetext{
3 “O mágico está para o cirurgião assim como o pintor está para o cinegrafista” (BENJAMIN, 2012, p. 27).
} 
abertura do primeiro Homo sacer: a vida "matável e insacrificável” (2007, p. 16), ou zoé, no sentido de estar vivo, vida "[...] desconexa de qualquer atividade cerebral e por assim dizer de sujeito", por oposição à "existência política", ou bíos, a vida politicamente qualificada, "vida de relação" (2017, p. 30).

Hans Belting propõe uma conexão entre os "não-lugares" de Augé e o conceito foucaultiano de "heterotopia" a propósito da antropologia das imagens: "a realidade virtual das imagens compreende uma região heterotópica: um espaço criado pela tecnologia, que é diferente do nosso mundo exterior" (BELTING, 2011, p. 43). No ápice da reprodutibilidade técnica, explorar os lugares vazios e reconstituir os lugares das imagens são formas de se contrapor, ou resistir ao processo de colonização que promove o desenraizamento das imagens, neutraliza o significado coletivo dos lugares e das imagens, transforma "lugares antropológicos" em "não-lugares". Todo lugar de imagens ou espaço icônico é heterotópico, seja como heterotopia de crise, quando o espaço tem função ritual, seja como heterotopia de desvio, típica da sociedade moderna, que exerce uma função normatizadora (FOUCAULT, 2009, p. 416). Heterotopias não são, segundo Foucault, necessariamente focos de resistência:

[...] lugares reais, lugares efetivos, lugares que são delineados na própria instituição da sociedade, e que são espécies de contraposicionamentos, espécies de utopias efetivamente realizadas nas quais os posicionamentos reais, todos os outros posicionamentos reais que se podem encontrar no interior da cultura estão ao mesmo tempo representados, contestados e invertidos, espécies de lugares fora de todos os lugares, embora eles sejam efetivamente localizáveis. (Foucault, 2009, p. 2015)

Sendo "delineados na própria instituição da sociedade", pertencem a ela, são extensões dela e os contraposicionamentos que abrigam não confrontam o que Foucault chama de "posicionamentos", os valores predominantes. Assemelhamse mais às figuras estudadas por Balandier (1980), como o trickster, ou heróitrapaceiro, o bobo da corte, o riso ritualmente prescrito e as inversões que ocorrem, por exemplo, nas festas de Carnaval, situações em que a fragilidade do poder evidencia-se por abalos momentâneos, mas que não levam à ruptura, uma vez que pertencem a um ciclo de ordem e desordem. Assim, uma 
"heterotopologia" distingue "heterotopias de crise" das "heterotopias do desvio", que, pelo caráter utilitarista das relações societárias, abandona os rituais em proveito da administração dos corpos e da gestão da vida.

Propomos chamar de "iconotopias" os lugares de imagens críticas, de imagens que exercem contraposicionamentos e resistem à vida nua na esquizofrenia e na irreferência das infovias. Podemos considerar uma vida politicamente qualificada das imagens, por oposição à vida nua das imagens, quando se trata de imagens que criam "iconochoques" (LATOUR, 2008, p. 117-118), que se encontram em lugares de imagens críticas, as iconotopias. Esses espaços são constituídos pelas obras de arte, como And yet my mask is powerful. Desde Debord, a deriva é um instrumento de criação de heterotopias. Os fluxos e usos dos espaços são subvertidos pelos percursos alternativos realizados pelos participantes dessas ações, performativas no sentido de que não descrevem o mundo, atuam sobre ele. Não são, nesse sentido, imagens. Porém o são os seus vestígios e registros. Os espaços onde ocorrem as derivas são apenas momentaneamente heterotópicos, tornam a ser lugares vazios, não-lugares, lugares de memória ou poder. O espaço de exposição dos vestígios e registros das derivas constituem as iconotopias, assim como os espaços onde ocorrem intervenções urbanas, como Aqui, de Renata Lucas (fig. 3). A palavra que designa o lugar onde se está foi escrita sobre a paisagem urbana de modo que só pode ser lida de um ponto de vista. Também constituem iconotopias as ações de grafiteiros e pichadores, como os desenhos de Vinicius Caps, produzidos com rolo e tinta látex nas ruas da capital paulista, retratando rostos e corpos com feições sertanejas (fig. 4). 


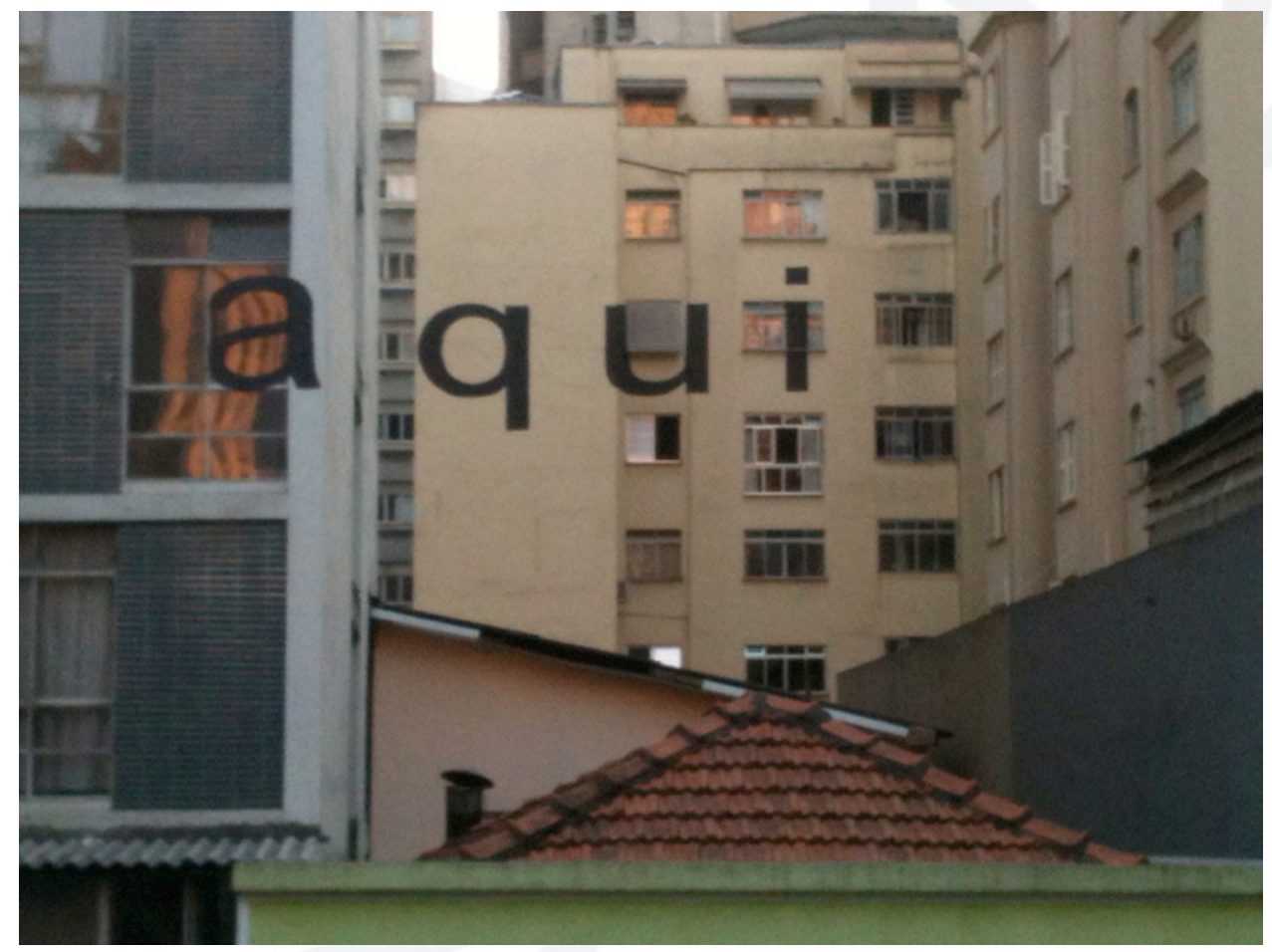

Figura 3: Aqui (Renata Lucas, 2017).

Foto do autor.

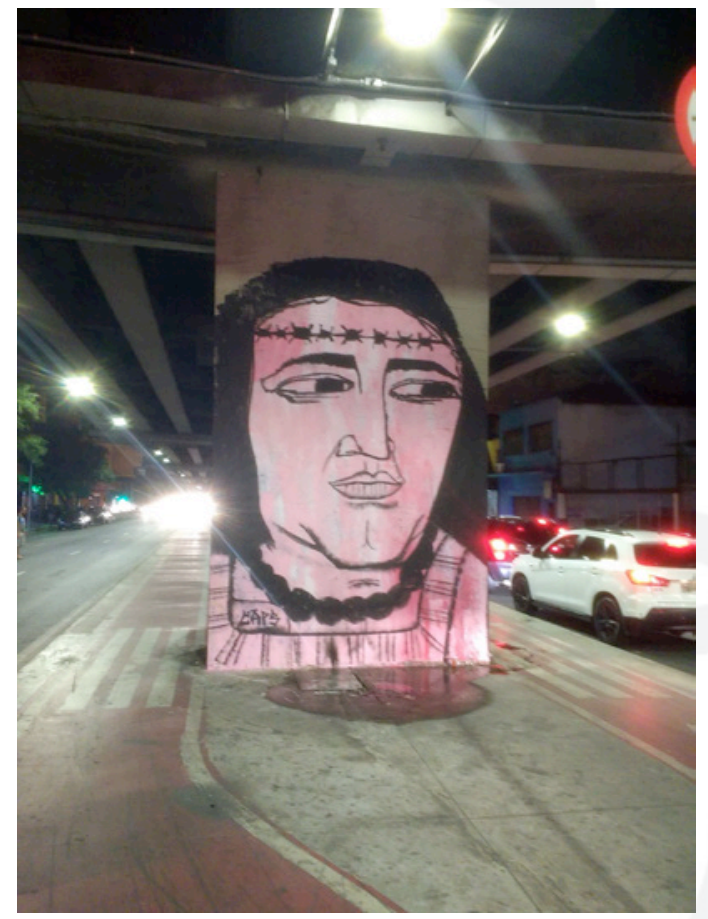

Figura 4: pintura de Vinicius Caps (pilar da via elevada João Goulart, 2017).

Foto do autor. 


\section{ANACRONISMOS}

O trabalho da dupla palestina, por sua vez, promove uma fusão entre a deriva e o desvio ao levar máscaras para os lugares, ao mesmo tempo recusando conscientemente a possibilidade da reconstituição e da reparação, sem pressupor uma identidade ou autenticidade, mas constituindo um amálgama de práticas e sentidos, um feixe de anacronismos equivalente à noção deleuziana de "cristal" (DELEUZE, 2005, p. 95) e à "constelação" segundo Benjamin (LÖWY, 2014, p. 119).

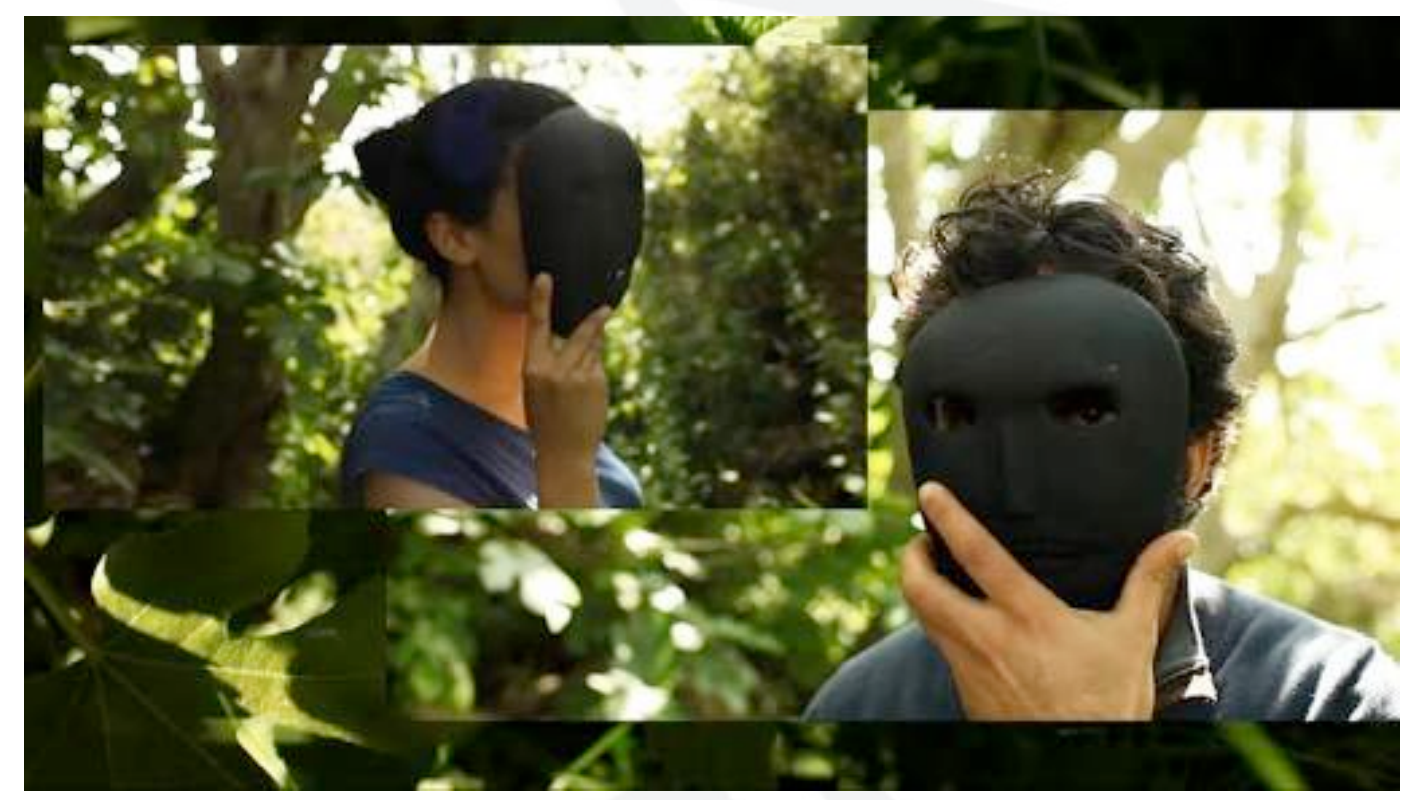

Figura 5: And yet my mask is powerful (still de vídeo). Fonte: Basel Abbas \& Ruanne Abou-Rahme (reproduzido sob permissão). 


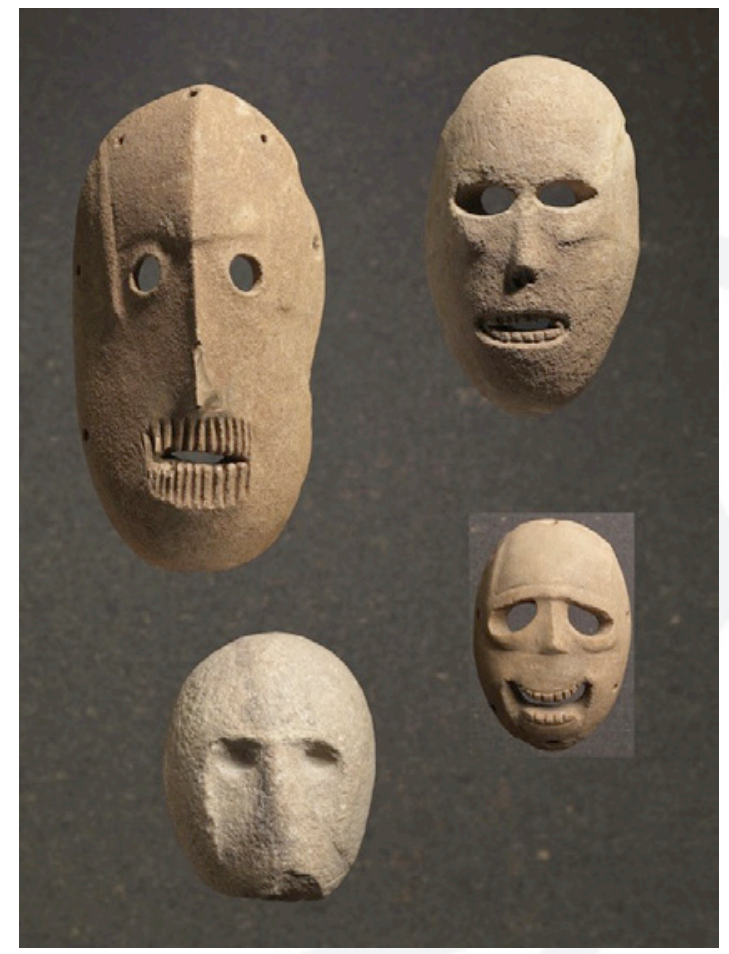

Figura 6: máscaras neolíticas do Museu de Jerusalém. Fonte: Live Science (divulgação).

A dupla palestina empregou a tecnologia da impressão tridimensional para reproduzir máscaras neolíticas, consideradas as "mais antigas do mundo", ${ }^{4}$ a partir de dados hackeados do Museu de Israel (figs. 5 e 6). 0 uso da impressão 3D é comum em diversas áreas, mas ainda era pouco acessível em 2008, quando Roberto Cuoghi escaneou a estatueta assíria de Pazuzu, que inspirou o livro $O$ exorcista, e utilizou a tecnologia para criar uma imagem de enormes proporções, como parte de Šuillakku (fig. 7), que significa "mão erguida", uma série de apropriações de referências à civilização assíria, que existiu na Mesopotâmia por três mil anos e reuniu mitos e rito de diversos povos antigos. O trabalho lembra And yet my mask is powerful, uma vez que apresenta uma grande diversidade de objetos, inclusive plantas e instrumentos musicais. Também é possível aproximar o trabalho da dupla palestina a Material speculation (MORESHIN ALLAYARI, 2016, fig. 8), um projeto de reconstituição

\footnotetext{
${ }^{4}$ Cf. notícia publicada pela agência Live Science em 13/03/2014.
} 
de esculturas assírias destruídas por militantes do Estado Islâmico. A artista iraniana, que vive e trabalha nos EUA, gravou informações sobre as esculturas em cartões de memória armazenados no interior das reproduções. Em seguida, divulgou essas informações pela internet, de modo que as esculturas destruídas fisicamanete sobrevivem nas infovias.

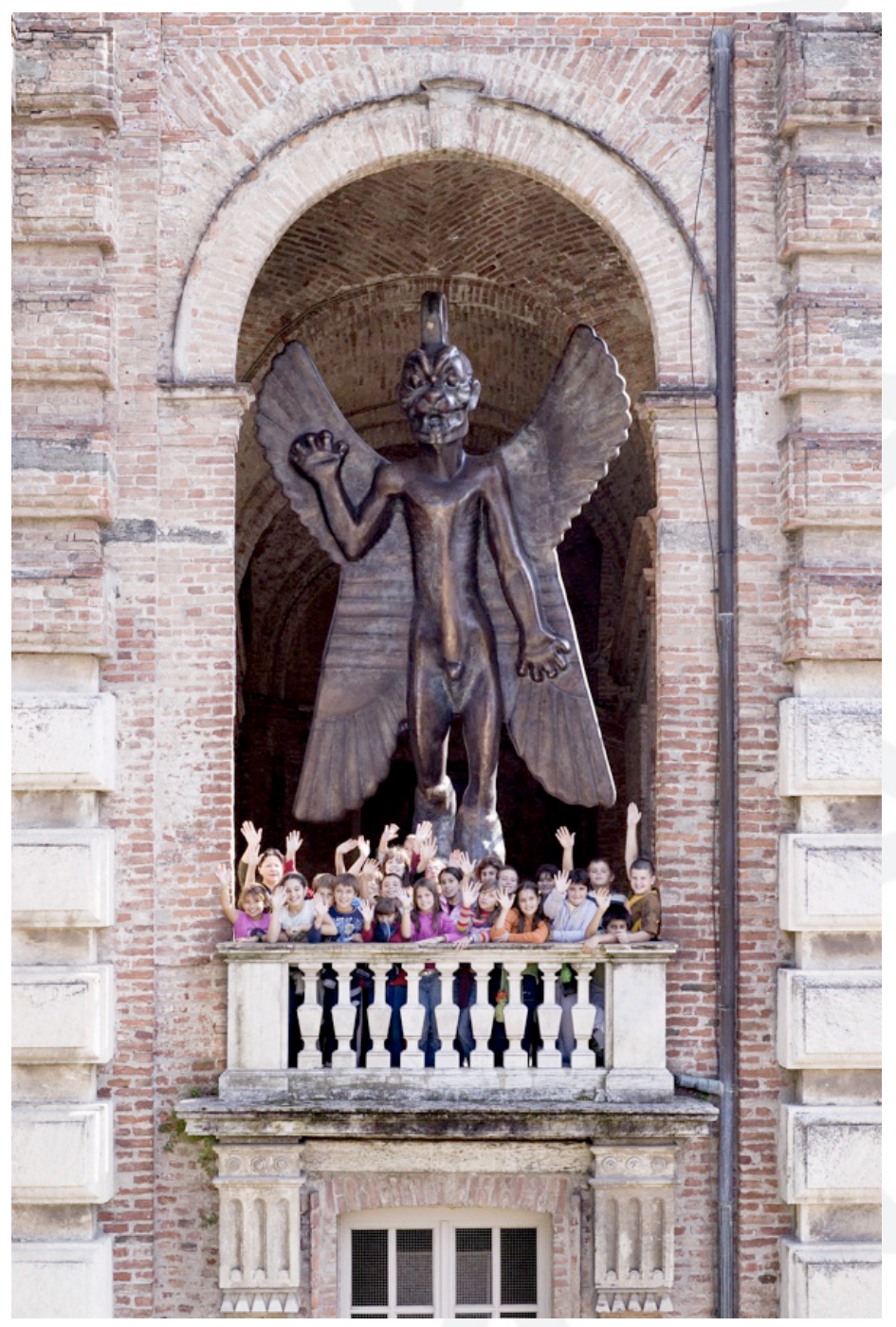

Figura 7: Pazuzu, de Roberto Cuoghi, 2008. Fonte: Castello di Rivoli (divulgação). 


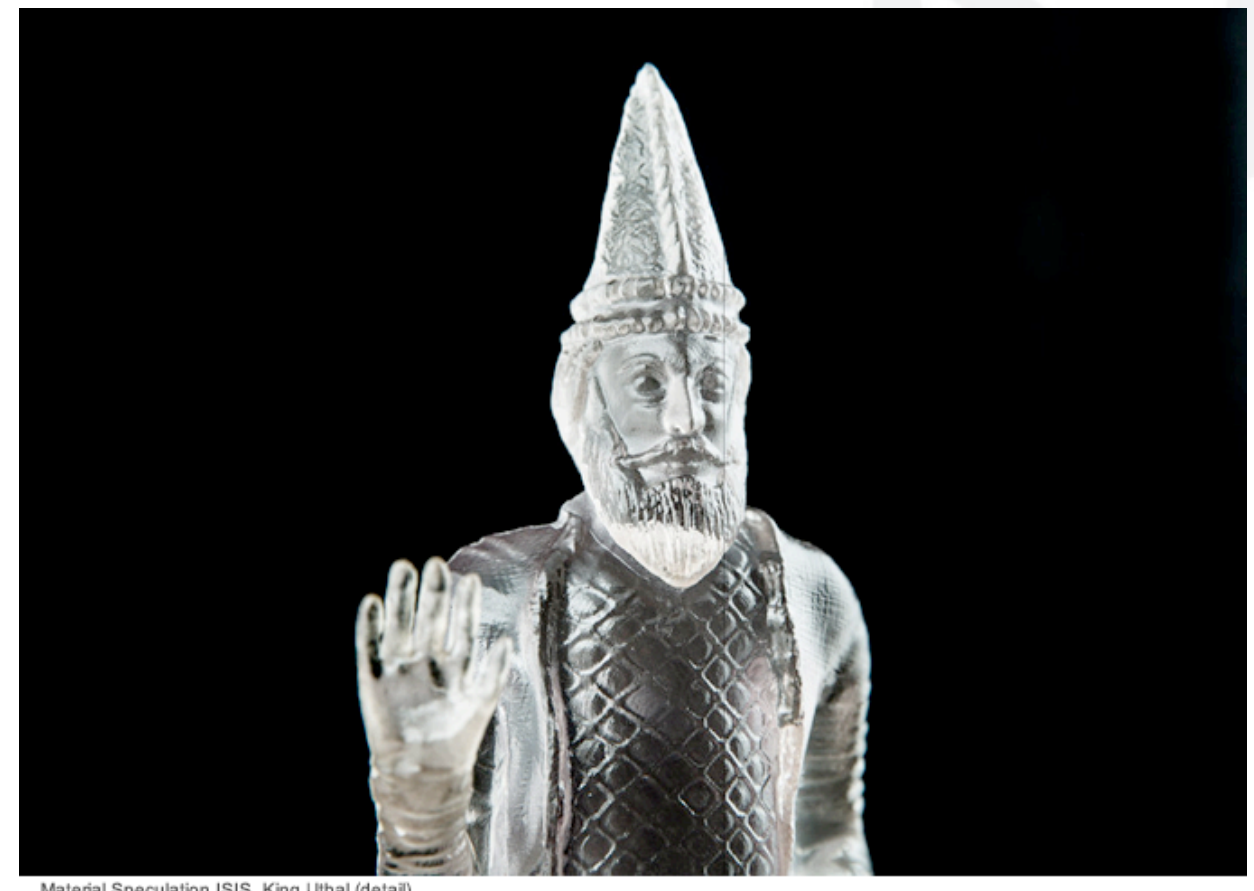

Figura 8: Material Speculation (2015-2016). Fonte: Moreshin Allayari (divulgação).

A utilização da impressão tridimensional, a conexão entre imagens e lugares, a importância da máscara para a antropologia das imagens e o regime da imagem na época da reprodutiblidade técnica transparecem na operação realizada por Ruanne Abou-Rahme e Basel Abbas. Uma das máscaras reproduzidas por eles foi levada de volta para o local onde fora encontrada. Ela não havia sido descoberta, mas removida da comunidade para a qual tinha um significado:

Essa é diferente, mais macia, suave e flexível. Parece uma face da lua, sua face redonda, a boca sorridente, os olhos semicerrados. Essa é a máscara de Ram. Havia um sítio neolítico aqui e aqui ficava a máscara, milhares de anos depois as pessoas do vilarejo ainda a usavam como um amuleto. Até que um médico inglês veio e a levou em 1881. Eles o perseguiram por causa disso, mas ele desapareceu. Então ela acabou fria e no escuro em Londres. Fossilizada. Morta. Sua expressão parecia mais triste agora que havia sido declarada morta e fechada por um vidro. Ficou ali por muito tempo, pouco vista e nunca tocada. Até que ela voltou para cá, nessa nova forma que lhe demos. Pode-se dizer que a cópia está lá e aqui, a coisa real. ${ }^{5}$

\footnotetext{
${ }^{5}$ Texto dos artistas.
} 
A visita da máscara com "face de lua" a Al-Ram, localidade habitada há milênios, a nordeste de Jerusalém, não tem poder de reparação, mas nessa limitação reside o potencial da obra de arte, ou imagem crítica, de expor o "estrago" e o "dano" (conforme o poema) causados pela experiência histórica, esse "naufrágio". O "iconochoque" (segundo Latour) ou "anacronismo" (segundo Didi-Huberman) promovido pelos artistas traz à tona os vínculos entre imagem, lugar e comunidade ao lembrar que "as pessoas a usavam como um amuleto" e denunciar que, depois de ter sido levada, sua condição como peça de museu é de imagem "fria", "fossilizada" e "morta", uma vez que foi capturada, aprisionada, "fechada por um vidro" nessa espécie de campo que são os museus, posta a serviço de "uma mitologia sobre o Estado" (conforme declaração citada anteriormente). Porém, assim como fizeram Roberto Cuoghi e Moreshin Allayari às suas maneiras e em diferentes contextos, a dupla palestina promove uma libertação da imagem, como se respondesse diretamente à injunção de Asger Jorn, "quebrem o quadro que sufoca a imagem", ${ }^{6}$ ao fazê-la circular no local onde ela teve uma vida politicamente qualificada, por oposição à vida nua das imagens no museu, esse campo de prisioneiros das guerras de imagens.

A reprodução da imagem, impressa a partir do formato digital, uma das facetas da vida nua das imagens, cria uma versão que, a princípio, seria vista como cópia, por oposição ao original autêntico. Contudo, o texto produzido pelos artistas, que pode ser visto, pela forma das instalações, como um desdobramento delas, ou como um dos elementos que as compõem (assim como as impressões de tela com imagens de relevos assírios, as plantas coletadas em meio às ruínas, os registros em vídeo das derivas com versos do poema em árabe e em inglês) qualifica a reprodução da máscara, o produto do trabalho de arte, como "coisa real", e a máscara original, a peça de museu, como "cópia".

A comparação com trabalhos que empregam procedimentos semelhantes demonstra a especificidade dessa relação obtida entre a "coisa real", uma

\footnotetext{
${ }^{6}$ Cartaz em apoio aos levantes estudantis de maio de 1968 em Paris.
} 
imagem verdadeira, e a cópia, a "vida nua" da imagem. Ao reencenar cânticos assírios e produzir uma réplica em escala sobre-humana da entidade mitológica Pazuzu, Roberto Cuoghi expõe o etnocentrismo das mentalidades ancoradas na oposição entre ocidente e oriente, que demoniza os deuses dos outros tanto nos textos sagrados judaicos, cristão e islâmicos, por um lado, quanto, por outro, na indústria cultural. A operação expõe uma solidariedade entre a indústria cultural e valores ou posicionamentos religiosos, demonstra que, ao promover a crença na técnica e no progresso, ela não promove senão um pretenso secularismo, uma "continuação do monoteísmo por outros meios" (LÜTTICKEN, 2009, p. 16). O romance e o filme $O$ exorcista (WILLIAM PETER BLATTY, 1972, 1971), praticamente idênticos, sugerem uma condenação moral às imagens católicas, às imagens da indústria cultural, aos deuses dos povos antigos, aos símbolos de poder e até mesmo ao imaginário infantil. Esse breviário corresponde a tal “[...] prática contemporânea de iconoclasmo secular" (LÜTTICKEN, 2009, p. 23). Com efeito, a possessão demoníaca ocorre durante as filmagens de uma superprodução cinematográfica que se passa na capital dos EUA e a criança visitada pelo demônio é contumaz produtora de estatuetas, justamente as "imagens esculpidas" proibidas pelo Decálogo. ${ }^{7}$ A mão erguida de Pazuzu, referida pelo termo šuillakku, por sua vez, é recorrente e está associada ao poder de intercessão para a cura, "salvação" e "proteção" (BELTING, 1994, p. 124). Ela contamina a iconografia cristã tardo-antiga, aparece em ícones bizantinos de Maria e Demétrio. Porém, a reprodução colossal criada por Roberto Cuoghi não questiona a condição da estatueta do Louvre (que mede $15 \mathrm{~cm}$. enquanto, no filme, aparece no tamanho de uma pessoa) nem trava novas relações que pudessem torná-la mais "real". Ela assume a condição de cópia, como a imagem pós-moderna, "esquizofrênica" segundo Jameson.

A mesma limitação ocorre em Material speculation. Moreshin Allayari reage ao controverso iconoclasmo dos militantes do grupo beligerante conhecido como

\footnotetext{
7 “Não terás outros deuses diante de mim. Não farás para ti imagem esculpida de nada que se assemelha ao que existe lá em cima, nos céus, ou embaixo, na terra, ou nas águas que estão debaixo da terra." (Êxodo 20-4, cf. BORTOLINI, p. 134).
} 
"Estado Islâmico", pela sigla em inglês ISIS e pelo acrônimo em árabe Daesh. Ao controlar cidades históricas que possuem sítios arqueológicos, como Mossul (antiga Nínive), Nimrud e Hatra, o grupo extremista promoveu espetáculos de destruição de imagens, fundamentando-se em citações corânicas que se reportam aos dois primeiros mandamentos do Decálogo; em parte, porém, não combatiam um culto religioso às imagens que pudesse ser condenado teologicamente como idolatria, era contra um apreço supostamente ocidental pelo valor cultural das imagens que as transmissões produzidas pelo Estado Islâmico se dirigiam. A artista iraniana radicada nos EUA não questiona a captura das imagens pela narrativa que lhes atribui um valor histórico ou cultural, ela reafirma essa narrativa, tendo sido premiada por isso pela UNESCO. Suas impressões tridimensionais de estátuas assírias e a vida digital que ela garante às imagens não rivalizam com os gestos iconoclastas dos militantes islamistas, pelo contrário, preservam-nos, uma vez que a premissa de Material speculation é que as imagens verdadeiras foram "materialmente" destruídas e o que resta é apenas uma memória. Não há ressurgimento, vida póstuma da imagem ou sobrevivência, mas apenas um código, um arquivo, a vida nua. Nem Roberto Cuoghi nem Moreshin Allayari questionam a diferença entre a cópia e a coisa real, entre a reprodução e a imagem verdadeira, como Ruanne Abou-Rahme e Basel Abbas com a apropriação de máscaras neolíticas nas derivas, registros e vestígios de And yet my mask is powerful.

O trabalho também chama atenção para o estranhamento entre o regime atual da imagem e o uso ritual de máscaras em povos tradicionais e na sociedade antiga. Mencionamos anteriormente o contraste entre heterotopias de crise e desvio proposto por Foucault. Na sociedade moderna, desprovida de vínculos comunitários e rituais, as heterotopias têm função normatizadora:

Mas essas heterotopias biológicas, essas heterotopias de crise, desaparecem cada vez mais e são substituídas por heterotopias de desvio: isto significa que os lugares que a sociedade dispõe em suas margens, nas paragens vazias que a rodeiam, são antes reservados aos indivíduos cujo comportamento é desviante relativamente à média ou à norma exigida. (Foucault, 2013, p. 22) 
A pintura facial, a tatuagem no rosto, mas principalmente a máscara são formas freqüentes de imagens associadas às "heterotopias de crise", à função ritual dos lugares e, por extensão, das imagens. As fotografias nos documentos de identidade, os perfis das redes sociais, a proibição do véu islâmico em países europeus, a automatização do reconhecimento facial nos sistemas de controle de passaporte e câmeras de vigilância evidenciam o teor biopolítico, de administração dos corpos e gestão da vida, da centralidade do rosto no imaginário global (a principal rede social da internet se chama Facebook). A origem dessa imagem da face remonta às fontes bizantinas do imaginário contemporâeno:

[...] a meditação sobre a face só pode apoiar-se nas raízes dogmáticas que fundaram o cristianismo como doutrina de outra frontalidade: a do rosto visível, do confronto bemsucedido porque redentor (MONDZAIN, 2013, p. 276).

Segundo a autora, a frontalidade da face culmina no "monopólio da visibilidade" que já foi detido pela Igreja e atualmente pertence à indústria cultural, ou se tornou um campo de batalha na guerra das imagens: "submeter-se a um concílio ou à CNN não apresenta grandes diferenças" (MONDZAIN, 2013, p. 284). Assim como a unicidade de Deus leva à associação do culto às imagens com a idolatria e o paganismo, a visibilidade do rosto faz com que a máscara desapareça. Por oposição à imagem verdadeira, oficial e original do rosto visível no documento, com seu poder de identificação, de abrir caminhos e permitir a passagem, a máscara assume a condição de ídolo, "uma imagem que é preciso matar" (MONDZAIN, 2013, p. 241). Se a visibilidade do rosto corresponde a uma gestão iconocrática e biopolítica da vida, a "matabilidade" da máscara está relacionada com uma função ritual, que por sua vez, corresponde à "analogia entre a imagem e a morte" (BELTING, 2011a, p. 84). É notável que, em 1881, o amuleto milenar de Al-Ram tenha sido levado por um médico.

A iconocracia, ou "organização do visível que provoca a crença" (MONDZAIN, 2000, p. 59), é um conceito ao mesmo tempo imaginal e espacial. Refere-se aos traços, cores e inscrições dos ícones, mas também à disposição dos ícones nas igrejas. Os choques de culturas causados pela colonização disseminam a 
pretensão iconocrática da Igreja, que se dedica a "utilizar ao máximo o intrumento da imagem, tentando mantê-la sob controle" (GRUZINSKI, 2006, p. 145). É exemplar o caso da Virgem de Guadalupe (GRUZINSKI, 2006, p. 165 e seguintes), que ocupa o lugar sagrado anteriormente dedicado à deusa Tonantzin e, ao invés de neutralizar o paganismo, passa a ser utilizada de modo incontrolável. Contudo, a colonização traz a "guerra das imagens" para o "interior da Igreja católica" (GRUZINSKI, 2006, p. 144) com desdobramentos que Gruzinski enxerga tanto no muralismo mexicano, que faz "eco aos muros de imagens", quanto na "hegemonia cultural e política" (GRUZINSKI, 2006, p. 297 e 299) da rede de TV Televisa:

Muros de imagens, telas às vezes gigantescas ocupando dezenas de metros quadrados, os afrescos cristãos não estão, como os painéis pré-Cortés, submersos na penumbra dos santuários que só os oficiantes podiam visitar. Participam de uma organização inédita do espaço, dos volumes e formas arquiteturais que os religiosos introduzem e arranjam progressivamente. (GRUZINSKI, 2006, p. 112)

O autor descreve o estranhamento indígena diante do antropomorfismo da visualidade cristã, que propõe os valores da encarnação e da individualidade. As descrições do historiador correspondem à definição de iconocracia segundo a socióloga Marie-José Mondzain ao ressaltar uma organização visual do espaço.

Na medida em que a iconocracia se desdobra das igrejas para as telas, os novos meios criam o novo contexto dos espaços ocupados por imagens sem corpos, que Belting denomina "iconomania”, utilizando uma expressão de Günther Anders:

A "mania de imagens, hoje reinante", ou "iconomania", como já Günther Anders Ihe chamou em 1956, explica-se, segundo ele, porque o homem, mediante a multiplicidade das imagens, gera para si uma existência múltipla e aspira a evadir-se assim da sua unicidade. Tentamos abolir os limites dentro dos quais se desenrola a nossa vida. O consumo simultâneo das mesmas imagens dá-nos, ademais, a sensação de viver num mundo sem barreiras sociais e culturais - o que é, sem dúvida, uma auto-ilusão. (...) Günther Anders cunhou o conceito de iconomania para designar uma nova dimensão na economia imaginal da sociedade. Identificou nesta mania a ilusão do homem de se multiplicar do mesmo modo que fazem os produtos técnicos. (BELTING, 2011b, p. 23-24) 
Belting esboça convergências e divergências entre espetáculo (Debord), simulação (Baudrillard) e iconomania. A crítica de Debord à "sociedade do espetáculo" não leva em consideração que toda relação social é "mediada por imagens" (2017, p. 38), não apenas o espetáculo. Sabe-se, porém, que se inaugura um novo regime da imagem com o primado das "sutilezas metafísicas" (2017, p. 51) da mercadoria, ou seja, o apagamento das marcas do trabalho, pressuposto da transformação do trabalho em mercadoria, o que define o modo de produção capitalista: "o modo capitalista passou a existir quando a riqueza monetária teve a capacidade de comprar a força de trabalho" (WOLF, 2009, p. 108). O fetiche da mercadoria seria análogo à reprodutibilidade técnica das imagens: "a reprodução mecânica parece retirar a responsabilidade do autor, assim como a imagem indicial parece ser um produto da natureza, não feito por mãos humanas" (LÜTTICKEN, 2009, p. 69).

A mercadoria, no modo de produção capitalista, é aquiropoética (não feita por mãos humanas), assim como a imagem sagrada. Sem as "sutilezas metafísicas e minúcias teológicas" (ŽIŽEK, 2012, p. 151) que associam o fetiche da mercadoria à filosofia da imagem, dificilmente se construiria uma ideologia. Marx descreve como relações sociais abstratas se travam entre seres genéricos e não entre indivíduos reais: uma "vida genérica por oposição à vida material" (MARX, 2010, p. 40). A causa da alienação iconomaníaca não é a imagem como propunha Debord, mas, conforme Baudrillard, a "[...] liquidação de todos os referenciais" ou a "ressurreição artificial" dos referenciais das imagens "nos sistemas de signos", como por exemplo, os códigos numéricos graças aos quais imagens digitalizadas prescindem de corpos, assim "inicia-se a era da simulação" na qual há "cada vez mais informação e cada vez menos sentido" (BAUDRILLARD, 1991, p. 9 e 103).

Ao contrário do espetáculo, que para Debord ainda possui referenciais reais separados (ou alienados), no contexto da simulação já não há mais a realidade, mas uma "hiper-realidade" na qual todos os elementos que pertencem à ordem do simulacro (a imagem que apaga o real, imagem sem referência real, índice sem protótipo), "o entretenimento, a arte, a informação e as tecnologias da informação fornecem experiências mais intensas e envolventes 
do que as cenas da vida banal" (MEDEIROS, p. 146). Belting descreve a iconomania como uma aspiração humana à condição imaterial que as infovias oferecem às imagens e que o fetiche da mercadoria já anuncia. Assim como diante dos anúncios no metrô descritos por Augé (BELTING, 2011a, p. 43), aspiramos a habitar os não-lugares e, entre eles, o não-lugar das infovias, esse “substituto tecnológico do Céu cristão" (BELTING, 2011b, p. 17).

O monopólio da visibilidade na sociedade moderna é exercido pelo olhar biopolítico e iconocrático sobre a imagem do rosto, causador da "violência do desvelo", que aprofunda a "mercantilização da subjetividade humana" (LÜTTICKEN, 2009, p. 159 e 161). As imagens que desviam da norma imposta por essa forma atual de organização do visível, sejam elas artísticas ou não, são capturadas nos campos de prisioneiros da guerra das imagens e levam, nas salas dos museus e nos acervos das galerias, uma "vida nua" comparável à da forma incorpórea das imagens digitalizadas, "pairando livremente" nos nãolugares das infovias. Tanto a obra de arte enquadrada pela instituição, posta a serviço de narrativas legitimadoras do poder que cria as instituições (a "mitologia sobre o Estado" de que falam os artistas palestinos), quanto a imagem digitalizada, sem corpo, a primeira transformada em informação, a segunda transformada em código, ambas existem, estão vivas, mas não vivem, não possuem uma vida politicamente qualificada, o que para uma imagem significa exercer um papel constitutivo para os laços de comunidade. A condição de vida nua vale para as duas formas de vida, ou sobrevida, das imagens, aquela que está aprisionada e a outra, que paira pelo mundo virtual, uma vez que, na chave de Agamben, “[...] o carrasco é, ele também, um cadáver vivo" (PELBART, 2016, p. 27).

Ao fazer circular a reprodução da máscara neolítica pelas ruínas das cidades palestinas no Estado de Israel, os artistas proporcionam para a imagem uma sobrevivência que não é sobrevida, vida nua, (em alemão, Überleben), mas a sobrevivência no sentido de Warburg e Tylor, a vida póstuma da imagem (em alemão, Nachleben): 
[...] a forma sobrevivente [...] desaparece num ponto da história, reaparece muito mais tarde, num momento em que talvez não fosse esperada, tendo sobrevivido, por conseguinte, no limbo mal definido da "memóra coletiva". (DIDI-HUBERMAN, 2013, p. 55)

O ressurgimento da imagem não promove uma reconstituição, uma vez que o significado que ela tinha como amuleto se perdeu com a destruição da comunidade, mas o procedimento artístico expõe as "temporalidades heterogêneas: nó de anacronismos" e "heterocronias" (DIDI-HUBERMAN, 2013, p. 52 e 56) que compõem as sociedades humanas segundo uma perspectiva antropológica, desconfigurando a história oficial a que a máscara original está a serviço em sua vida nua no museu.

Os estudos de Belting indicam uma relação forte da imagem com a experiência da morte. Assim como o papel institucional do rosto visível nos documentos e infovias associa-se à gestão da vida, a máscara proporciona uma "memória petrificada" do ancestral, é portadora dos "signos sociais do corpo vivo" (BELTING, 2011a, p. 89 e 87). Ainda segundo uma perspectiva antropológica, todo retrato seria potencialmente funerário "ainda que não mostrasse o rosto do morto" (JUNQUEIRA, 2015, p. 23). A prática do rito funerário seria uma espécie de "fato social total", uma vez que, dada a transitoriedade dos membros, a continuidade da comunidade depende da preservação da memória, uma "quarta obrigação" (GODELIER, 2001, p. 160 e 49) que compõe o sistema de trocas recíprocas que Mauss chamou de dom ou dádiva, aquela que se deve aos ancestrais. Todo rito funerário pressupõe a imagem, uma vez que o cuidado com o cadáver se dá na consciência da ausência da pessoa: "no momento da morte, o cadáver necessariamente se torna uma imagem" (BELTING, 2011a, p. 85). Portanto é plausível a hipótese de que a produção de imagens seja tão antiga quanto os ritos funerários.

Essas observações antropológicas se complementam por um outro elemento do trabalho And yet my mask is powerful: a história remota do local onde se encontram as cidades destruídas. A região onde foram encontradas as máscaras neolíticas abriga os assentamentos humanos mais antigos que conhecemos, onde ocorreram as primeiras experimentações com o cultivo de grãos. Em poucos 
milênios, o sedentarismo e as práticas agrícolas espalharam-se por quase todo o planeta. Pouco se sabe sobre a simbologia dos povos paleolíticos, mas os sítios arqueológicos onde se encontravam algumas das máscaras neolíticas são também os lugares onde foram encontradas as imagens mais antigas cujos cultos são conhecidos, os "crânios de Jericó", achados pela arqueóloga Kathleen Kenyon e comentados por Hans Belting no estudo sobre as relações entre a imagem e a morte. Face imperecível feita para esconder o rosto perecível, a máscara "torna visível uma ausência" (BELTING, 2011a, p. 93), assim como toda imagem funerária. Os crânios possuem faces artificiais semelhantes a máscaras, mas contêm algo do corpo no seu interior, como relicários.

A máscara depende do corpo que a utiliza para a sua "animação" (BELTING, 2006 , p. 40 ), assim como pinturas faciais e tatuagens, enquanto a imagem esculpida, por sua vez, separada do corpo, anima-se apenas com o olhar, um procedimento menos físico e mais mental. A ação dos artistas resgata a máscara da condição estática em que está aprisionada no museu e permite que ela se anime novamente.

\section{BIBLIOGRAFIA}

ADORNO, Theodor W. Kulturkritik und Gesellschaft vol. I. Frankfurt: Suhrkamp, 2003.

AGAMBEN, Giorgio. Homo sacer. Belo Horizonte: Editora UFMG, 2007.

O aberto. Rio de Janeito: Civilização Brasileira, 2017.

ARENDT, Hannah. Eichmann em Jerusalém. São Paulo: Companhia das Letras, 2017.

AUGÉ, Marc. Por uma antropologia da mobilidade. Maceió: Unesp / EDUFAL, 2010.

Não-lugares. Campinas: Papirus, 2003.

BALANDIER, Georges. O poder em cena. Brasília: Editora da UNB, 1980.

BAUDRILLARD, Jean. Simulacros e simulação. Lisboa: Relógio d'Água, 1991.

BELTING, Hans. An anthropology of images. Princeton: Princeton University Press, 2011a.

A verdadeira imagem. Porto: Dafne, 2011b. 
Imagem, mídia e corpo. Ghrebh n. 8. São Paulo: CISC, 2006.

Likeness and presence. Chicago: The University of Chicago Press, 1994.

BENJAMIN, Walter et alt. Benjamin e a obra de arte. Rio de Janeiro: Contraponto, 2012.

BLATTY, William Peter. O exorcista. Petrópolis: Nova Fronteira, 1972.

BORTOLINI, José (coord. ed.). A Bíblia de Jerusalém. São Paulo: Paulus, 1995.

BOURRIAUD, Nicolas. Pós-produção. São Paulo: Martins Fontes, 2009.

BÜRGER, Peter. Teoria da vanguarda. São Paulo: Cosacnaify, 2008.

DANTO, Arthur C. Transfiguração do lugar-comum. São Paulo: Cosacnaify, 2005.

DEBORD, Guy. A sociedade do espetáculo. Rio de Janeiro: Contraponto, 2017.

DELEUZE, Gilles. A imagem-tempo. São Paulo: Brasiliense, 2005. Diálogos. São Paulo: Escuta, 1998.

DIDI-HUBERMAN, Georges. Diante do tempo. Belo Horizonte: Editora UFMG, $2015 a$.

Falenas. Lisboa: KKYM, 2015b.

A imagem sobrevivente. Rio de Janeiro: Contraponto, 2013.

Sobrevivência dos vaga-lumes. Belo Horizonte: Editora UFMG, 2011.

DUBY, Gerorges (org.). História da vida privada vol. 2. São Paulo: Companhia das Letras, 2009.

FERREIRA, José Bento. Arte extemporânea, Bahiaciência n. 2. São Paulo: Aretê, 2014.

FOUCAULT, Michel. O corpo utópico, as heterotopias. São Paulo: n-1, 2013. Outros espaços, Ditos \& escritos III. Rio de Janeiro: Forense universitária, 2009.

GELL, Alfred. Art and agency. Oxford: Clarendon Press, 1998.

GODELIER, Maurice. O enigma do dom. Rio de Janeiro: Civilização Brasileira, 2001.

GRUZINSKI, Serge. A guerra das imagens. São Paulo: Companhia das Letras, 2006.

HUYSSEN, Andreas. Culturas do passado-presente. Rio de Janeiro:

Contraponto, 2014.

JAMESON, Fredric. Pós-modernidade e sociedade de consumo, Novos estudos. n. 12, São Paulo: CEBRAP, 1985.

JUNQUEIRA, Carolina dos Santos. O corpo, a morte, a imagem. Belo Horizonte: tese apresentada ao Programa de Pós-Graduação em Artes da EBA/UFMG, 2015. 
KRAUSS, Rosalind. A escultura no campo ampliado, Arte \& Ensaios n. 17, Rio de Janeiro: EBA, UFRJ, 2008.

LATOUR, Bruno. O que é iconoclash? Ou, há um mundo além das guerras de imagem?, Horizontes Antropológicos. Porto Alegre, ano 14, n. 29, 2008.

LÖWY, Michael. Aviso de incêndio. São Paulo: Boitempo, 2014.

LÜTTICKEN, Sven. Idols of the market. Nova York / Berlim: Sternberg, 2009.

MARX, Karl. Sobre a questão judaica. São Paulo: Boitempo, 2010.

MEDEIROS, Rogério. Enigmas e paradoxos da imagem na era do simulacro, Arte \& Ensaios n. 15, Rio de Janeiro: EBA, UFRJ, 2007.

MONDZAIN, Marie-José. Iconic space and the rule of lands. Hypatia. vol. 15 no. 4, Indiana University Press, 2000.

Imagem, ícone, economia. Rio de Janeiro: Contraponto, 2013.

NORA, Pierre. Les lieux de mémoire. Paris: Gallimard, 1992.

PELBART, Peter Pál. O avesso do niilismo. São Paulo: n-1, 2016.

$\mathrm{RICH}$, Adrienne. Diving into the wreck, disponivel em: http://www.library.yale.edu/ nkuhl/lit100b/Adrienne\%20Rich.pdf

TASSINARI, Alberto. O espaço moderno. São Paulo: Cosac \& Naify, 2001.

WOLF, Eric R. A Europa e os povos sem história. São Paulo: Edusp, 2009.

WOLLHEIM, Richard. A pintura como arte. São Paulo: Cosac \& Naify, 2002.

ŽIŽEK, Slavoj. Vivendo no fim dos tempos. São Paulo: Boitempo, 2012.

\section{LISTA DE FIGURAS}

Figura 1: And yet my mask is powerful, still de vídeo. Fonte: Basel Abbas \& Ruanne Abou-Rahme (reproduzido sob permissão). pág.: 116

Figura 2: And yet my mask is powerful, vista da instalação.

Fonte: Basel Abbas \& Ruanne Abou-Rahme (reproduzido sob permissão). pág.: 116

Figura 3: Aqui (Renata Lucas, 2017). Foto do autor. pág.: 124

Figura 4: pintura de Vinicius Caps (pilar da via elevada João Goulart, 2017). Foto do autor. pág.: 124

Figura 5: And yet my mask is powerful (still de vídeo). Fonte: Basel Abbas \& Ruanne Abou-Rahme (reproduzido sob permissão). pág.: 125

Figura 6: máscaras neolíticas do Museu de Jerusalém. Fonte: Live Science (divulgação). pág.: 126

Figura 7: Pazuzu, Roberto Cuoghi, 2008. Fonte: Castello di Rivoli (divulgação). pág.: 127

Figura 8: Material Speculation (2015-2016). Fonte: Moreshin Allayari (divulgação). pág.: 128 